\title{
Now Disease Reports \\ First report of a variant of Pepper leaf curl Lahore virus on winter cherry in India
}

\author{
A. Srivastava, S.K. Snehi and S.K. Raj*
}

Plant Molecular Virology, CSIR-National Botanical Research Institute, Rana Pratap Marg, Lucknow-226001, U.P., India

*E-mail: skraj2@rediffmail.com

Received: 06 Oct 2012. Published: 19 Feb 2013. Keywords: Solanum capsicastrum, begomovirus, PepLCLV

Solanum capsicastrum (family Solanaceae) known as winter cherry, is grown in pots and beds in gardens for its ornamental value. There is a previous record of natural occurrence of a strain of Eggplant mottled crinkle virus on S. capsicastrum (Raj et al., 1988). During September 2011, a leaf curl disease was observed on more than $40 \%$ plants of $S$ capsicastrum growing in gardens at Lucknow, India. The infected plants exhibited severe leaf curl accompanied by green blisters and distortions (Fig. 1). The causal agent was successfully transmitted in an insect proof glasshouse from naturally infected to healthy seedlings through whiteflies (Bemisia tabaci). This produced similar symptoms indicating Begomovirus infection.

Presence of a Begomovirus was confirmed by PCR using the total DNA extracted from leaf samples and Begomovirus specific primers (Rojas et al., 1993) producing $1.2 \mathrm{~kb}$ amplicons in naturally as well as experimentally inoculated $S$. capsicastrum plants. For molecular identification of the Begomovirus, the full-length DNA-A molecule of 2740 bp long was amplified by rolling circle amplification (RCA) using TempliPhi 100 Amplification Kit (GE Healthcare UK Limited) followed by restriction digestion with $B a m H I$, cloned, and sequenced; the sequence was deposited in GenBank (Accession No. JN880419). Sequence analysis of the Begomovirus isolate under study (JN880419) using the BLASTn programme revealed $93 \%$ identity with Pepper leaf curl Lahore virus (PepLCLV) (AM691745), PepLCLV-[Pakistan:Lahore1:2004] (AM404179) and PepLCLV-[Pakistan:Lahore2:2004] (AM491589) of Capsicum аппиит from Pakistan. It also showed 90-91\% identity with Pepper leaf curl Bangladesh virus isolates (HM007101, HM007096, DQ116881) of $C$. апnиum from India and Pakistan. As per the criteria proposed by Fauquet et al. (2008), the Begomovirus infecting $S$. capsicastrum was proposed as a variant of PepLCLV-[Pakistan:Lahore1:2004] and was named as PepLCLV-[Solanum capsicastrum: Lucknow: India]. Phylogenetic

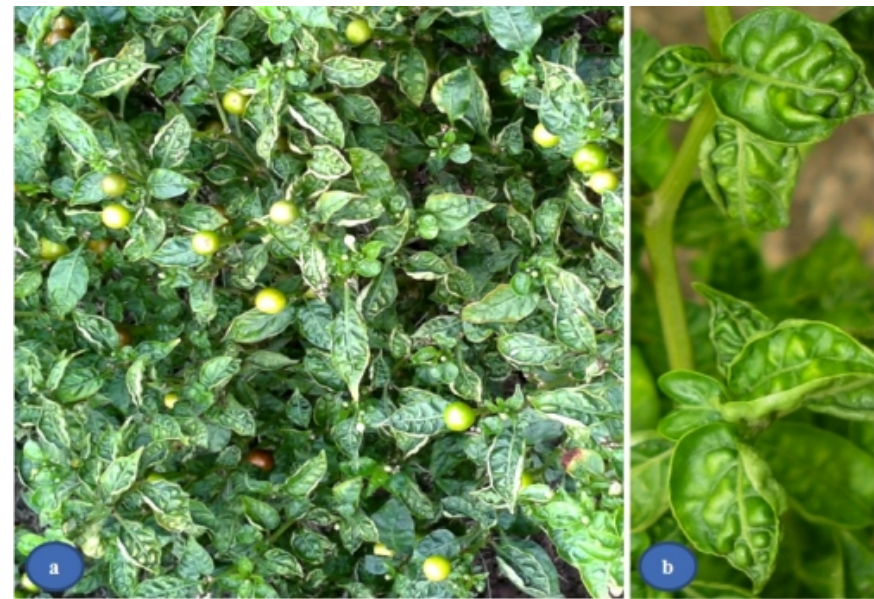

Figure 1 analysis also supported BLASTn analysis since the PepLCLV- $[S$ capsicastrum] variant clustered in a single distinct branch that embraces PepLCLV (Fig. 2). The reports of natural occurrence of PepLCLV on $C$. annuum from Pakistan (Tahir et al., 2010) and Eggplant mottled crinkle virus on $S$. capsicastrum from India (Raj et al., 1988) are available in the literature. However, the Begomovirus infection on $S$. capsicastrum is being reported for the first time from India.

\section{Acknowledgements}

Authors are thankful to the Director, CSIR-National Botanical Research Institute, Lucknow, India for facilities and Yashwant Kumar Singh for virus maintenance.

\section{References}

Fauquet CM, Briddon RW, Brown JK, Moriones E, Stanley J, Zerbini M, Zhou X, 2008. Geminivirus strain demarcation and nomenclature. Archives of Virology 153, 783-821.

[http://dx.doi.org/10.1007/s00705-008-0037-6]

Raj SK, Srivastava KM, Aslam M, Singh BP, 1988. Occurrence of a strain of eggplant mottled crinkle virus in Solanum capsicastrum in India. Plant Pathology 37, 599-603.

[http://dx.doi.org/10.1111/j.1365-3059.1988.tb02122.x]

Rojas MR, Gilbertson RL, Russell DR, Maxwell DP, 1993. Use of degenerate primers in the polymerase chain reaction to detect whitefly transmitted geminiviruses. Plant Disease 77, 340-347.

[http://dx.doi.org/10.1094/PD-77-0340]

Tahir M, Haider MS, Briddon RW, 2010. Chili leaf curl betasatellite is associated with a distinct recombinant begomovirus, Pepper leaf curl Lahore virus, in Capsicum in Pakistan, Virus Research 149,109-114. [http://dx.doi.org/10.1016/j.virusres.2009.12.007]

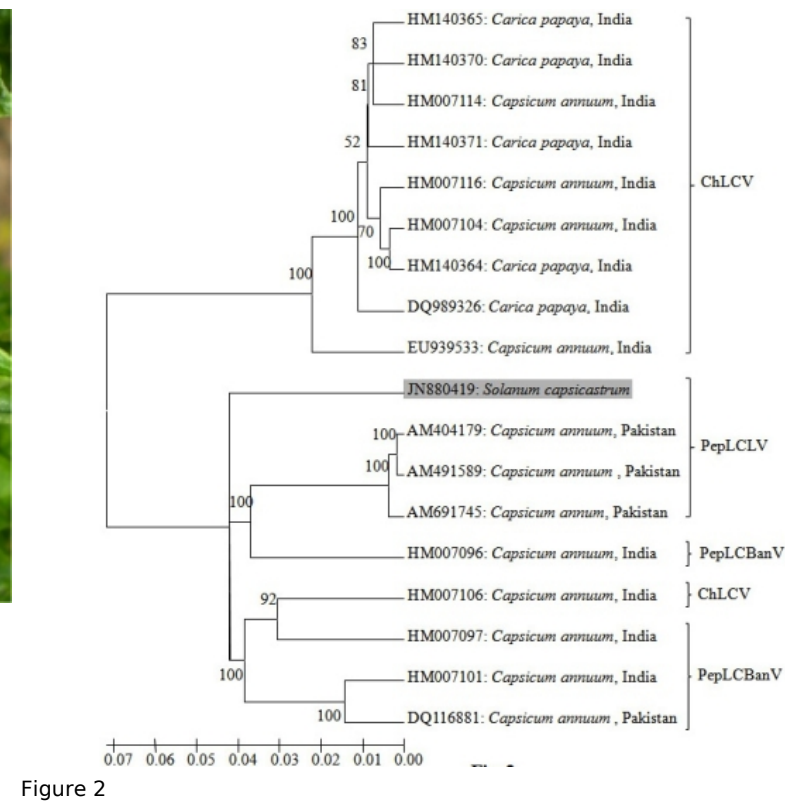

Figure 2

To cite this report: Srivastava A, Snehi SK, Raj SK, 2013. First report of a variant of Pepper leaf curl Lahore virus on winter cherry in India. New Disease Reports 27, 7. [http://dx.doi.org/10.5197/j.2044-0588.2013.027.007]

(c) 2013 The Authors

This report was published on-line at www.ndrs.org.uk where high quality versions of the figures can be found. 